\title{
Editorial
}

\section{RETHINKING OUR POLITICAL AND CULTURAL PARADIGMS...}

With this issue, the Journal enters its 5th year of publication. And as I contemplate the year ahead of us, I have good reason to be grateful for how far the Journal has traveled, thanks to all of you, whether members of our Associate Editors internal review committee, the International Advisory Board, authors, reviewers, readers. I am enormously grateful for the unstinting efforts all of you have made to make this Journal recognized nationwide.

At the same time, I am also fully aware of the challenges we face in 2007 particularly around the ongoing debates and struggles around the issue of immigration, the regularization of the status of millions of Latino/as who currently find themselves in limbo, and the wars - both in our cities and overseas - that, in addition to thousands of Iraquis, are also killing so many Latino/a and non-Latino/a youth.

I look forward to another year of vigorous discussions in the pages of the Journal as a way of continuing our commitment as scholars and researchers - as public intellectuals - to keeping a permanent bridge between the world of academia and the lived experiences of Latino/as in our communities. It is the possibility of nurturing a substantive dialogue between the two that I find essential as a means of contributing, even in a small way, to the effort to move this society toward greater understanding of the presence and contributions of Latino/as.

If these 4 years have shown me anything, it is the realization that our collective Latinismo has not resulted in the negation of the differences in national origins, which impinge on intra-Latino/a relations. Recognition of the ties that bind us together, that connect us to scholar-activists who are not Latino/as but who continue to demonstrate an interest in and support for Latino/a causes, especially through their engagement in Latino Studies, is a clear testimony to the exigency of ensuring that our Journal can continue to be a quality publication whose reach and impact involve both Latino/as and non-Latino/as.

The essays in this issue focus on, revisit and in some cases redefine the political and cultural paradigms that both frame and underlie the contemporary discourses and practices embedded in the Latino/a experience. In so doing, their authors challenge us to reflect on, rethink and redefine various aspects of our society's traditional practices of inclusion and exclusion. Hector Amaya, for example, discusses the case of young Latinos who, having died in Iraq, are today being granted posthumous citizenship. 
In so doing, he re-situates American liberalism and the granting of posthumous citizenship the broader context of the history of US imperialism, class and racial stratification. Mary Kay Davalos explores the ways that Chicana art collectors challenge the practices of federal and public museums, and, in the process redefine the very meaning of art collecting in a broader US third-world feministactivist perspective. Alfredo González focuses on the emerging and changing sexual practices and identities among Latino youth on the "down low" in the context of the historical and political construction of ethno-racial identities. He calls for a re-examination of the ways that current racial-ethnic definitions of identity impact on public health and HIV prevention strategies. Luis Alvarez analyzes the ways that the inter-cultural poetics of racialized Black, Latino and Asian youth can function as both a struggle for dignity and a possible solution for the current crises of resources and domination in the academy. Pointing to the ways that Chicano/a youths' identity is shaped by their interactions with other racialized groups, his article forcefully argues for a need to revitalize our cultural and theoretical paradigms in both Ethnic and Chicano/Latino studies. Guillermo Irizarry explores alternative notions of production and consumption in the context of an examination and critique of Latino's cultural hybridization and the problematics of community, its sense of project and destiny, its vehement impulse toward domesticating difference, and its program for hegemonizing subalternity.

Grounded in the acknowledgement of our political, structural and cultural commonalities as well as in the exchanges with other gendered, sexual, racialized and socially marginalized groups - the authors in this issue all aim to disrupt traditional understandings of long-standing hegemonic discourses and practices in US society. In so doing, they call on us to rethink our approach to the Latino/a experience in a larger political and cultural context. We are also proud to present an interview by José González with the Puerto Rican poetactivist, essayist and public intellectual, Martin Espada, in the Vivencias section of this issue.

Finally, I also includes all the reviewers who have helped us with the publication of our journal over the past year. Once again, I thank all of you for your help and support.

Saludos!

Suzanne Oboler

University of Illinois, Chicago

Latino Studies (2007) 5, 1-2. doi:10.1057/palgrave.lst.8600243 